\title{
PERBANDINGAN METODE GABUNGAN HISTOGRAM EQUALIZATION DENGAN CONTRAST STRETCHING UNTUK PERBAIKAN KUALITAS CITRA RADIOLOGI
}

\author{
${ }^{[1]}$ Muhammad Aprilian, ${ }^{[2]}$ Sampe Hotland Sitorus, ${ }^{[3]}$ Uray Ristian \\ [1] [2] [3] Jurusan Rekayasa Sistem Komputer, Fakultas MIPA Universitas Tanjungpura \\ Jl. Prof. Dr. H. Hadari Nawawi, Pontianak \\ Telp./Fax.: (0561) 577963 \\ e-mail: ${ }^{[1]}$ muhammad_aprilian@student.untan.ac.id, ${ }^{[2]}$ sitorus.hotland@gmail.com, \\ ${ }^{[3]}$ eristian@siskom.untan.ac.id
}

\begin{abstract}
ABSTRAK
Pembacaan hasil gambar radiologi memiliki beberapa hambatan dari hasil gelap, hasil cerah, dan noise. Penelitian ini bertujuan untuk membangun sistem peningkatan kualitas untuk hasil radiologis gambar paru-paru. Sistem peningkatan kualitas gambar radiologis akan dibangun dengan menerapkan dan membandingkan dua metode Histogram Equalization (HE) dan Contrast Stretching (CS). Metode Histogram Equalization digunakan untuk meratakan distribusi abu-abu gambar. Metode Contrast Stretching digunakan untuk memperluas distribusi gambar abu-abu. Dalam penelitian ini kedua metode tersebut digabungkan untuk melihat optimalisasi kedua metode tersebut. Dari 20 hasil perbaikan gambar yang dianalisis oleh para ahli, persentase masing-masing metode diperoleh. Untuk metode HE menghasilkan persentase $15 \%$, untuk metode CS menghasilkan persentase $0 \%$, untuk metode gabungan CS-HE menghasilkan persentase $75 \%$ dan untuk metode gabungan HE-CS menghasilkan persentase 10\%. Jadi dapat disimpulkan bahwa metode yang lebih baik untuk meningkatkan kualitas gambar radiologis adalah metode gabungan CS-HE.
\end{abstract}

Kata Kunci : Citra Radiologi, Diagnosa, Histogram Equalization, Contrast Stretching.

\section{PENDAHULUAN}

Radiologi adalah suatu ilmu tentang penggunaan sumber sinar pengion dan bukan pengion, gelombang suara dan magnet untuk imaging diagnostik dan terapi [1]. Dalam membaca hasil citra radiologi terdapat beberapa kendala dari hasil yang terlalu gelap, hasil yang terlalu putih, bahkan beberapa informasi dari citra kurang jelas atau terdapat noise. Untuk mengdiagnosa penyakit paru-paru dilakukanlah proses radiografi untuk mendapatkan hasil citra radiologi. Hasil citra radiologi tersebut akan dibaca oleh pakar untuk mendiagnosa penyakit paru-paru. Dalam membaca hasil citra radiologi ini sering menjadi permasalahan bagi para dokter untuk menentukan diagnosa dari hasil citra radiologi. Bagi para operator radiologi juga sering mengalami hasil citra radiologi yang ditangkap kurang baik, sehingga mereka harus melakukan pengaturan untuk mendapatkan hasil citra yang baik.

Berdasarkan uraian di atas maka perlu dibangun sistem perbaikan kualitas untuk hasil radiologi citra paru-paru. Sistem perbaikan kualitas citra radiologi akan dibangun dengan menerapkan dan membandingkan dua metode Histogram Equalization dan Contrast Stretching. Dengan membandingkan dua metode tersebut diharapkan dapat meningkatkan kualitas citra radiologi penyakit paru-paru sehingga mempermudah dokter dan operator radiologi dalam menentukan metode yang paling baik untuk sistem perbaikan kualitas citra radiologi.

Sehubungan dengan penelitian perbaikan kualitas citra digital, beberapa peneliti telah melakukan penelitian berjudul "Pengaruh Histogram Equalization untuk Perbaikan Kualitas Citra Digital" [2]. Hasil penelitian ini membuktikan bahwa penggunaan metode Histogram Equalization dapat digunakan untuk meningkatkan kontras citra dan dapat meningkatkan kualitas citra, sehingga informasi yang ada pada citra lebih jelas terlihat. Penelitian selanjutnya dengan judul "Metode Histogram Equalization untuk Perbaikan Kualitas Citra Digital" [3]. Hasil yang diberikan oleh metode Histogram Equalizaton dalam penelitian ini 
dapat meningkatkan kualitas citra, sehingga informasi yang ada pada citra lebih jelas terlihat.

Penelitian selanjutnya dengan judul

"Analisis Contrast Stretching Menggunakan Algoritma Eculedian untuk Meningkatkan Kontras pada Citra Berwarna" [4]. Hasilnya contrast stretching tidak hanya dapat digunakan pada citra grayscale namun citra berwarna dapat juga diterapkan dalam metode tersebut. Penelitian selanjutnya dengan judul "Implementasi Contrast Stretching untuk Perbaikan Kualitas Citra Digital" [5]. Hasil dari penelitian ini membuktikan bahwa Contrast Stretching menyebabkan penyebaran nilai RGB menjadi merata. Penyebaran nilai RGB yang merata menyebabkan citra memiliki kontras yang lebih baik dari citra asli sebelum perbaikan.

Berdasarkan penelitian terkait dan permasalahan yang didapat, maka dilakukan penelitian dengan judul "Perbandingan Metode Gabungan Histogram Equalization dengan Contrast Stratching untuk Perbaikan Kualitas Citra Radiologi". Dengan penelitian ini diharapkan membantu para pengguna dalam membaca hasil citra radiologi dengan kualitas yang lebih baik.

\section{TINJAUAN PUSTAKA}

\subsection{Citra Digital}

Pengolahan citra digital dimulai sekitar awal tahun 1920-an dari dunia pemberitaan media cetak, dimana sebuah citra dikirim melalui kabel bawah laut dari London menuju ke New York [6]. Proses transmisi ini menghemat waktu pengiriman dari seminggu menjadi kurang dari tiga jam. Sebelum dikirim, citra terlebih dulu dikodekan dan setelah diterima citra direkonstruksi ulang. Contoh ini sebenarnya masih kurang tepat digunakan sebagai awal mula pengolahan citra digital karena dalam prosesnya belum menggunakan teknologi komputer.

Suatu citra dapat didefinisikan sebagai fungsi $f(x, y)$ berukuran $M$ baris dan $N$ kolom, dengan $\mathrm{x}$ dan $\mathrm{y}$ adalah koordinat spasial, dan amplitudo $f$ di titik koordinat $(\mathrm{x}, \mathrm{y})$ dinamakan intensitas atau tingkat keabuan dari citra pada titik tersebut. Apabila nilai $\mathrm{x}, \mathrm{y}$, dan nilai amplitudo $f$ secara keseluruhan berhingga (finite) dan bernilai diskrit maka dapat dikatakan bahwa citra tersebut adalah citra digital. Sebuah citra digital dapat dituliskan dalam bentuk matriks MxN seperti pada Persamaan 1:

$$
f(x, y)=\left[\begin{array}{cccc}
f(0,0) & f(0,1) & \cdots & f(0, N-1) \\
f(1,0) & f(1,1) & \cdots & f(1, N-1) \\
\cdots & \cdots & \cdots & \cdots \\
f(M-1,0) & f(M-1,1) \cdots & f(M-1, N-1)
\end{array}\right]
$$

\subsection{Citra Grayscale}

Citra grayscale merupakan citra digital yang memiliki nilai intensitas $0=$ hitam sampai $255=$ putih [7]. Rentang ini berarti bahwa setiap piksel dapat direpresentasikan oleh delapan bit atau satu byte. Citra grayscale dapat digunakan untuk merepresentasikan citra medis (sinar-X), tulisan. Citra grayscale dengan 256 level abuabu dapat digunakan untuk mengenali kebanyakan objek. Untuk mencari piksel Grayscale dapat digunakan Persamaan 2.

$$
\text { Grayscale }=\frac{R+G+B}{3}
$$

Dimana,

$$
\begin{array}{lll}
\text { Grayscale } & & =\text { piksel Grayscale } \\
R & & =\text { piksel merah } \\
G & & =\text { piksel hijau } \\
B & & =\text { piksel biru }
\end{array}
$$

\subsection{Paru-Paru}

Paru-paru adalah organ pada sistem respirasi (pernapasan) yang terletak dalam rongga thorax [8]. Fungsi paru-paru sebagai tempat pertukaran oksigen dari udara dengan karbon dioksida dari darah. Paru kanan terbagi dari dua fisura menjadi tiga lobus, yaitu: superior, media, dan inferior. Paru kiri dibagi oleh sebuah fisura menjadi dua lobus, yaitu: superior dan inferior. Tampilan struktur paruparu seperti pada Gambar 1.

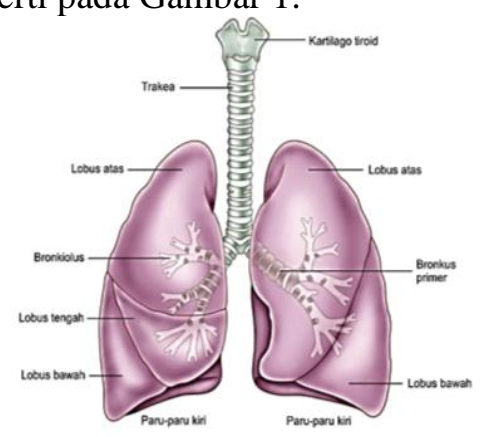

Gambar 1. Struktur Paru-Paru

\subsection{Radiologi}

Radiologi adalah suatu ilmu tentang penggunaan sumber sinar pengion dan bukan pengion, gelombang suara dan magnet untuk imaging diagnostik dan terapi [9]. Bidangbidang yang ada di dalam radiologi adalah sebagai berikut: 
1. Radiodiagnostik, merupakan bagian dari cabang ilmu radiologi yang memanfaatkan sinar pengion untuk membantu diagnosa dalam bentuk foto yang bisa didokumentasikan.

2. Radioterapi, merupakan salah satu regimen terapi untuk penyakit terutama keganasan dengan menggunakan sinar pengion/radioaktif.

3. Kedokteran nuklir, adalah bidang kedokteran yang memanfaatkan materi radioaktif (radioisotop) untuk menegakkan diagnosis dan mengobati penderita serta mempelajari penyakit manusia. Dapat juga untuk pemeriksaan dinamika organ misalnya pemeriksaan fungsi jantung dan ginjal.

4. Ultrasonografi, merupakan pengguna gelombang suara frekuensi sangat tinggi/ultrasonik (3,5-5 $\mathrm{MHz})$ untuk membantu diagnosis. Ultrasound adalah gelombang suara dengan frekuensi lebih dari $20.000 \mathrm{~Hz}$. Yang digunakan dalam bidang kedokteran antara 1-10 MHz.

5. MRI (magnetic resonance imaging), merupakan teknik diagnosa yang memanfaatkan medan magnet dan gelombang frekuensi radio (RF). Pemeriksaan tidak menimbulkan radiasi ionisasi, dan dapat diperoleh hasil berupa penampang dari berbagai arah.

\subsection{Histogram Equalization (HE)}

Histogram citra merupakan tool yang digunakan untuk mengetahui sebaran tingkat keabuan suatu citra [10]. Informasi sebaran tingkat keabuan tersebut sangat bermanfaat untuk memisahkan objek dengan latar belakang dari suatu citra. Pada bahasa histogram telah dijelaskan, bahwa dengan menggunakan histogram dapat diketahui informasi frekuensi pemakaian tingkat keabuan dalam suatu citra. Equalisasi histogram merupakan metode untuk memperbaiki kualitas citra dengan cara mengubah sebaran tingkat keabuan citra. Hal ini dimaksudkan agar sebaran tingkat keabuan lebih merata dibandingkan dengan citra aslinya.

Tahapan untuk melakukan Histogram Equalization adalah sebagai berikut:

1. Mengelompokkan dan menghitung jumlah piksel berdasarkan nilai keabuannya.

2. Memindai histogram dari nilai keabuan 0 sampai 255 untuk menemukan batas nilai keabuan terendah dan batas nilai keabuan tertinggi dari kelompok piksel (citra).

3. Menghitung peluang kemunculan setiap intensitas piksel $\left(P_{r}\right)$ seperti pada Persamaan 3 dan menghitung distribusi kumulatifnya $(S k)$ (proses normalisasi) seperti pada Persamaan 4:

$$
P_{r}\left(r_{k}\right)=\frac{n_{k}}{n}
$$

Dimana,

$$
\begin{array}{ll}
\begin{array}{ll}
P_{r}\left(r_{k}\right) & =\text { peluang kemunculan piksel } \\
n_{k} & \text { =jumlah piksel yang muncul pada } \\
& \text { intensitas tertentu } \\
& =\text { jumlah keseluruhan piksel pada } \\
& \text { suatu citra }
\end{array} \\
\begin{aligned}
S_{k}=T\left(r_{k}\right)=\sum_{j=0}^{k} \frac{n_{j}}{n}=\sum_{j=0}^{k} P_{r}\left(r_{j}\right) \\
\text { Dimana, } \\
\quad 0 \leq r_{k} \leq 1, k=0,1,2, \ldots, L-1
\end{aligned}
\end{array}
$$

4. Membulatkan hasil perkalian distribusi kumulatif $\left(S_{k}\right)$ dengan jumlah variansi nilai keabuan terbesar yang muncul(L$1)$.

5. Mengskalakan piksel-piksel hasil dengan cara mengkalikan hasil pembulatan dengan skala keabuan yang digunakan 255 untuk citra 8 bit, seperti pada Persamaan 5. Hasil dari pengsekalaan dibulatkan dengan menggunakan Persamaan 6:

$$
\begin{gathered}
S=\left|S_{k}\right| x 255 \\
\text { round } S=\left|S_{k}\right| x 255
\end{gathered}
$$

\subsection{Contrast Stretching (CS)}

Kontras dalam suatu citra menyatakan distribusi warna terang dan gelap. Suatu citra berskala keabuan dikatakan memiliki kontras rendah apabila distribusi warna cenderung pada jangkauan arah keabuan yang sempit [11]. Sebaliknya, citra mempunyai kontras tinggi apabila jangkauan arah keabuan lebih terdistribusi secara melebar. Kontras dapat diukur berdasarkan perbedaan antara nilai intensitas tertinggi dan nilai intensitas terendah yang menyusun piksel-piksel dalam citra.

Cara kerja dari proses peregangan kontras (Contrast Stretching) pada citra 8 bit adalah sebagai berikut:

1. Mengelompokkan dan menghitung jumlah piksel berdasarkan nilai keabuannya.

2. Memindai (scan) histogram dari nilai keabuan terkecil ke nilai keabuan terbesar (0 sampai 255) untuk menemukan batas 
nilai keabuan terendah dan batas nilai keabuan tertinggi dari kelompok piksel (citra).

3. Memetakan (menskalakan) piksel-piksel yang berada di antara batas terendah dan batas tertinggi untuk memenuhi rentang nilai-nilai keabuan yang lengkap (0 sampai 255), dengan mengunakan Persamaan 7 (Pee, 2016):

$Y=\left(X-x_{\min }\right)\left(\frac{l_{\max }-l_{\min }}{x_{\max }-x_{\min }}\right)+l_{\min }$

Dimana,

$Y \quad=$ nilai keabuan yang baru

$X \quad=$ nilai keabuan yang lama

$x_{\min }=$ nilai keabuan terendah

$x_{\max }=$ nilai keabuan tertinggi

$l_{\min }=$ nilai keabuan terendah yang diinginkan

$l_{\max }=$ nilai keabuan tertinggi yang diinginkan

\section{METODOLOGI PENELITIAN}

Untuk membuat sistem perbaikan kualitas citra radiologi, metode penelitian yang digunakan dapat dilihat pada Gambar 2.

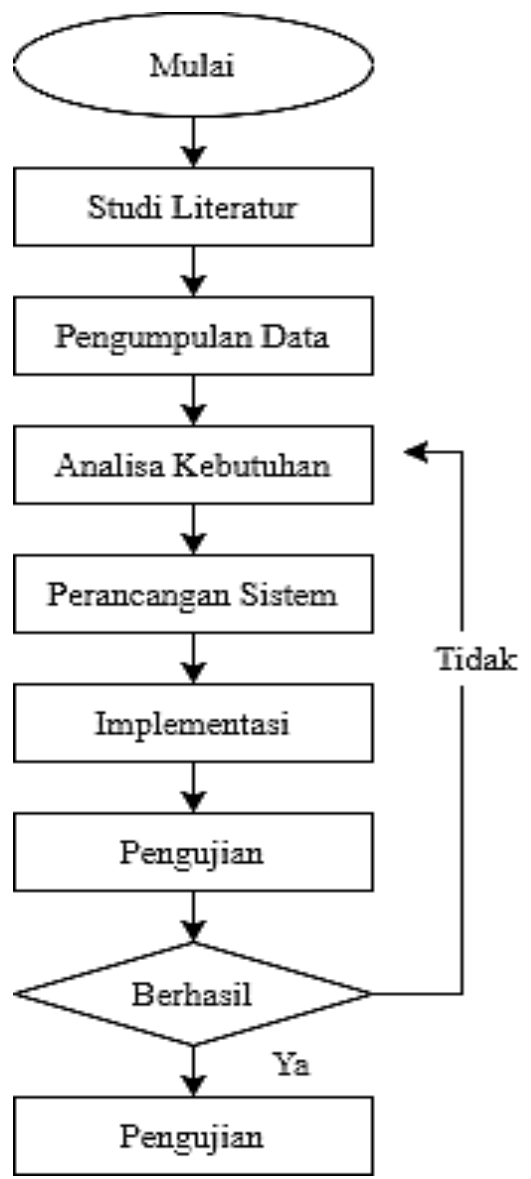

Gambar 2. Flowchart Penelitian

\section{PERANCANGAN}

\subsection{Rancangan Sistem}

Pada perancangan sistem ini, komponen sistem dirancang dengan tujuan untuk membandingkan metode Histogram Equalization dan Contrast Stretching. Metode yang terbaik akan dijadikan metode untuk sistem perbaikan kualitas citra. Secara garis besar, sistem yang akan dibangun menggunakan bahasa pemrograman php. Sistem ini bekerja dengan melakukan proses perbaikan citra radiologi dengan masing-masing metode yang digunakan. Dalam hal ini objek penelitian yang digunakan adalah citra radiologi. Gambaran rancangan sistem secara umum ditampilkan pada Gambar 3 .

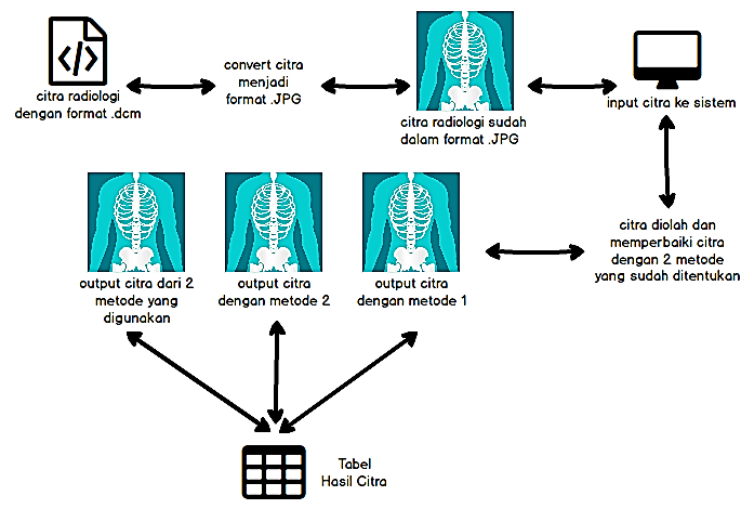

Gambar 3. Rancangan Sistem Secara Umum Adapun penjelasan lebih lanjut dari sistem ini adalah sebagai berikut:

1. Gambar hasil radiologi diambil langsung dari Unit Pelaksana Teknis (UPT) Kesehatan Paru-Paru Pontianak. Hasil radiologi yang digunakan adalah hasil radiologi thorax para pasien yang ada di UPT terkait.

2. Setelah data didapat maka sebelum diproses data dikonversi terlebih dahulu menjadi format JPEG.

3. Setelah dikonversi citra tersebut dimasukan ke dalam sistem aplikasi website untuk diproses.

4. Pada tahapan ini citra yang sudah dimasukan ke dalam sistem akan diproses dan dilakukan proses resize citra terlebih dahulu sebesar 500x500 piksel. Proses resize bertujuan mengefisienkan waktu dalam proses sistem. Selanjutnya sistem akan melakukan perbaikan citra yang sudah di resize menggunakan metode Histogram Equalization dan Contrast Stretching. Hasil perbaikan citra akan disimpan ke database agar bisa diakses kembali nantinya. 


\subsection{Flowchart Metode Histogram Equalization} Pada Gambar 4 dapat dilihat flowchart metode Histogram Equalization aplikasi perbaikan kualitas citra radiologi. Flowchart metode Histogram Equalization adalah urutan yang digunakan dalam proses perbaikan kualitas citra menggunakan metode Histogram Equalization.

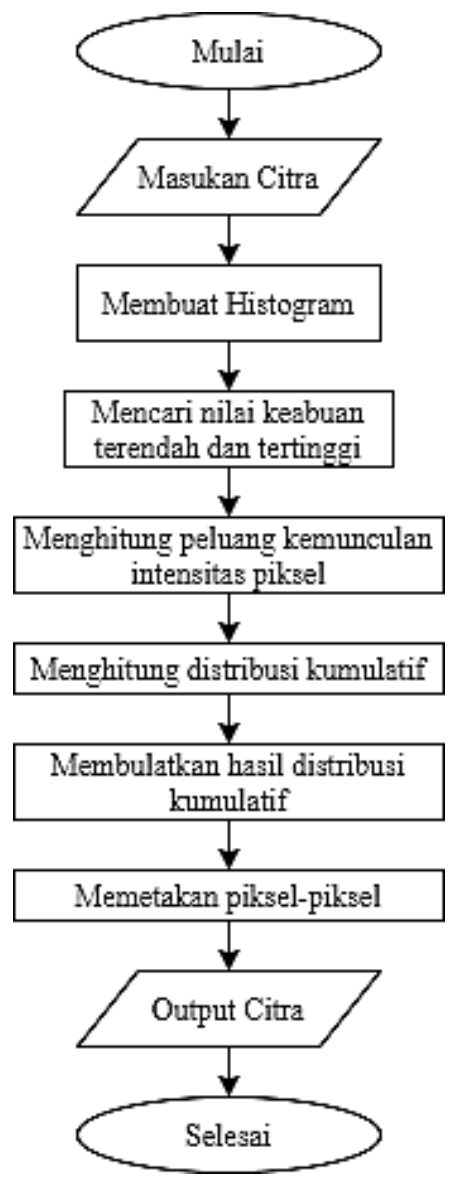

Gambar 4. Flowchart Histogram Equalization

Penjelasan rincian dari masing-masing tahapan akan dijelaskan sebagai berikut:

1. Proses dimulai.

2. Masukan citra yang akan diproses.

3. Mengelompokkan dan menghitung jumlah piksel berdasarkan nilai keabuannya (membuat histogram).

4. Memindai (scan) histogram dari nilai keabuan 0 sampai 255 untuk menemukan batas nilai keabuan terendah dan batas nilai keabuan tertinggi dari kelompok piksel (citra).

5. Menghitung peluang kemunculan setiap intensitas piksel $\left(P_{r}\right)$ menggunakan Persamaan 3 dan menghitung proses normalisasi atau distribusi kumulatifnya (Sk) menggunakan Persamaan 4.
6. Membulatkan hasil perkalian distribusi kumulatif $\left(S_{k}\right)$ dengan jumlah variansi nilai keabuan terbesar yang muncul (L-1).

7. Memetakan piksel-piksel hasil dengan cara mengkalikan hasil pembulatan dengan skala keabuan yang digunakan 255 untuk citra 8 bit menggunakan Persamaan 5. Hasil dari pengskalaan dibulatkan dengan Persamaan 6.

8. Proses selesai.

\subsection{Flowchart Metode Contrast Stretching}

Pada Gambar 5 dapat dilihat flowchart metode Contrast Stretching aplikasi perbaikan kualitas citra radiologi. Flowchart metode Contrast Stretching adalah urutan yang digunakan dalam proses perbaikan kualitas citra menggunakan metode Contrast Stretching.

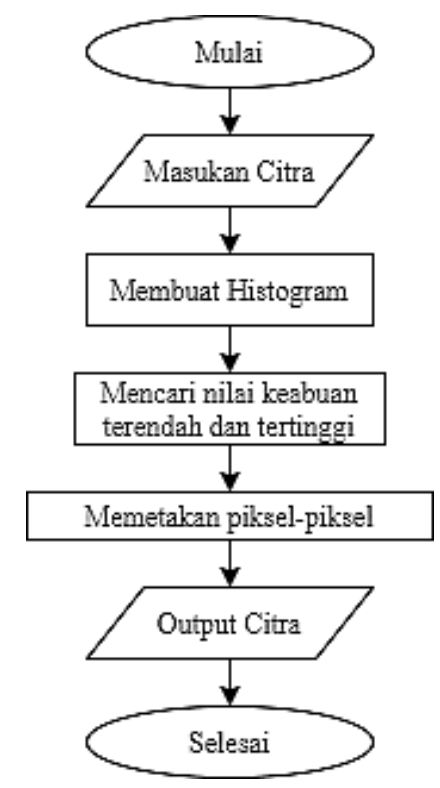

Gambar 5. Flowchart Contrast Stretching

Penjelasan rincian dari masing-masing tahapan akan dijelaskan sebagai berikut:

1. Proses dimulai.

2. Masukan citra yang akan diproses.

3. Mengelompokkan dan menghitung jumlah piksel berdasarkan nilai keabuannya.

4. Memindai histogram dari nilai keabuan terkecil ke nilai keabuan terbesar (0 sampai 255) untuk menemukan batas nilai keabuan terendah dan batas nilai keabuan tertinggi dari kelompok piksel citra.

5. Menskalakan piksel-piksel yang berada di antara batas terendah dan batas tertinggi untuk memenuhi rentang nilai-nilai keabuan yang lengkap (0 sampai 255) menggunakan Persamaan 7. 


\section{Proses selesai.}

\subsection{Flowchart Pengujian}

Gambar 6 berisi flowchart pengujian perbaikan citra yang diolah oleh kedua metode Histogram Equalization dan Contrast Stretching. Pada pengujian ini menghasilkan keluaran berupa citra radiologi yang sudah diperbaiki.

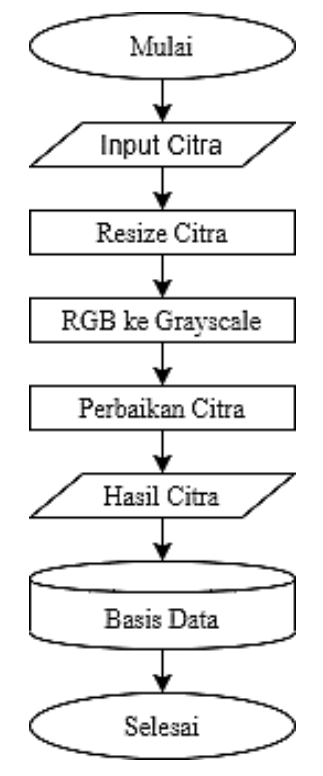

Gambar 6. Flowchart Pengujian

Penjelasan rincian dari masing-masing tahapan akan dijelaskan sebagai berikut:

1. Proses dimulai dengan melakukan input citra yang akan diproses ke aplikasi.

2. Masukan citra yang akan diproses.

3. Tahapan dilanjutkan dengan resize citra yang akan menghasilkan citra berukuran 500 x 500 piksel. Tujuan dari resize citra agar meringankan kerja aplikasi sehingga waktu eksekusi program dapat dilakukan lebih cepat.

4. Selanjutnya citra dikonversi dari RGB ke Grayscale.

5. Citra hasil konversi selanjutnya dilakukan tiga proses dengan dua metode yaitu Histogram Equalization, Contrast Stretching, dan gabungan kedua metode. Proses ini akan menghasilkan citra radiologi yang sudah diperbaiki.

6. Hasil dari perbaikan citra akan ada 4 keluaran yaitu hasil menggunakan Histogram Equalization, Contrast Stretching, dan gabungan kedua metode tersebut.
7. Selanjutnya hasil dari perbaikan tersebut akan disimpan di database untuk nantinya dapat diakses kembali oleh user.

8. Proses selesai.

\section{IMPLEMENTASI, PENGUJIAN, DAN PEMBAHASAN}

\subsection{Implementasi Perangkat Lunak}

Dari perancangan sistem yang telah dilakukan, diperlukan adanya implementasi dan pengujian untuk mengetahui tercapai tidaknya tujuan dari penelitian. Implementasi dilakukan untuk mengetahui apakah tampilan dari aplikasi sudah sesuai sedangkan pengujian dilakukan untuk mengetahui sistem telah berjalan dengan baik dan sesuai dengan fungsi yang diinginkan.

Pada halaman login admin terdapat kolom username dan password yang harus diisi untuk masuk ke halaman admin. Tampilan halaman login admin ditunjukkan pada Gambar 7. Selanjutnya masuk ke halaman profile admin, disini admin dapat menggunakan fitur reset untuk mengubah foto profile dan password. Tampilan halaman profile admin ditunjukan pada Gambar 8.

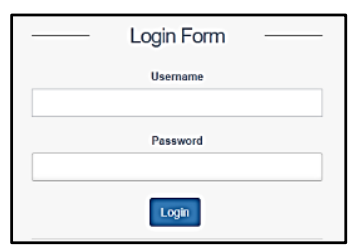

Gambar 7. Halaman Login Admin

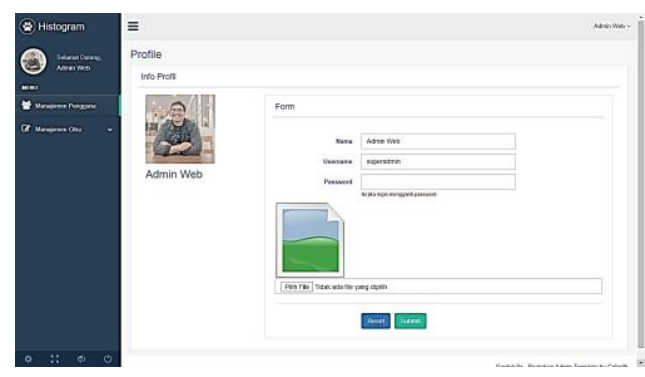

Gambar 8. Tampilan Halaman Profle Admin

Pada menubar terdapat dua menu yaitu menu manajemen pengguna dan manajemen citra. Fitur manajemen citra terdapat dua fitur slidebar yaitu proses Histogram Stretching dan Log. Tampilan slidebar pada menu manajemen citra dapat dilihat pada Gambar 9. 


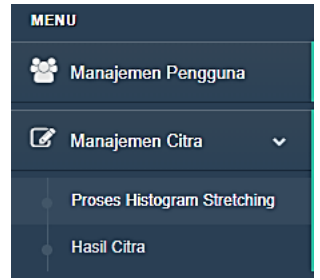

Gambar 9. Tampilan Slidebar Manajemen Citra

Fitur slidebar pertama adalah fitur proses Histogram Stretching. Pada halaman fitur ini terdapat fitur yang berfungsi untuk memasukan citra radiologi yang akan diperbaiki. Tampilan halaman proses Histogram Stretching dapat dilihat pada Gambar 10.

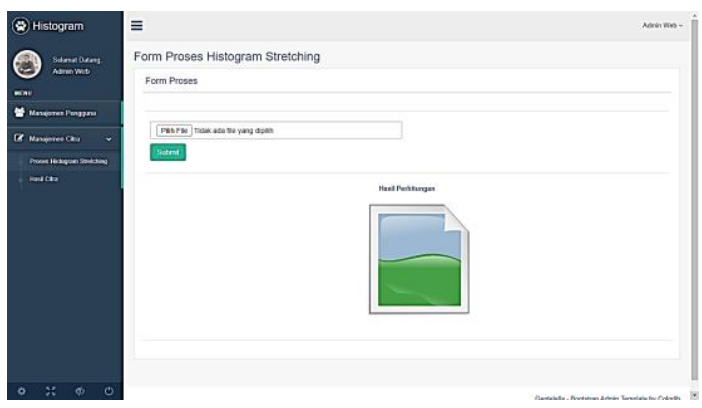

Gambar 10. Halaman Proses Histogram Stretching

Selanjutnya citra akan ditampilkan seperti pada Gambar 11 sebelum diproses oleh sistem. Menampilkan citra masukan berguna untuk memastikan citra yang akan proses apakah sudah benar.

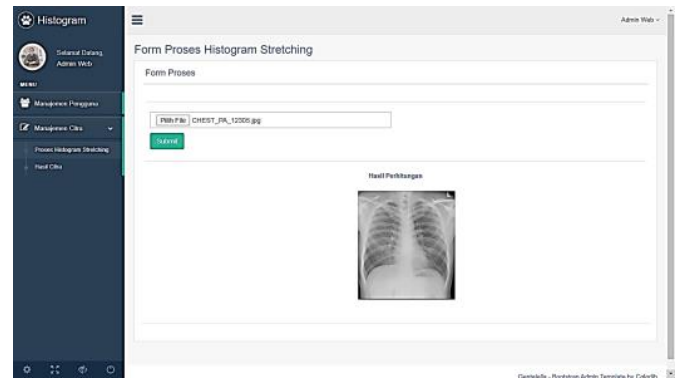

Gambar 11. Tampilan Proses Masukan Citra

Pada halaman ini terdapat tombol submit yang berfungsi untuk memproses citra yang sudah diinputkan sebelumnya. Pada proses ini citra akan diperbaiki kualitasnya dan menghasilkan keluaran dari metode Histogram Equalization, Contrast Stretching, dan gabungan metode. Hasil dari perbaikan citra akan ditampilkan seperti pada Gambar 12.

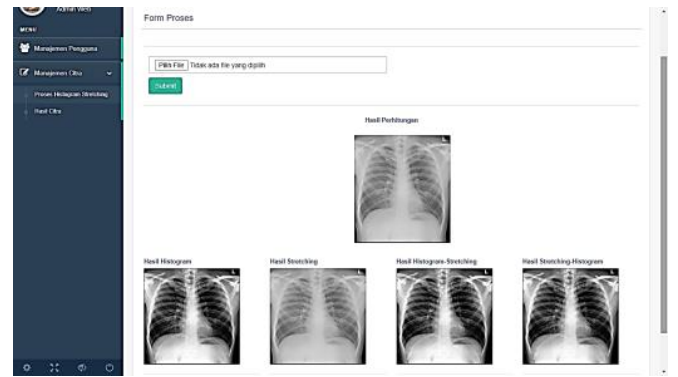

Gambar 12. Tampilan Hasil Proses Perbaikan

Citra

Pada Gambar 13 merupakan halaman hasil citra dimana halaman ini menampilkan tabel hasil citra yang sudah diperbaiki. Pada halaman ini terdapat tabel citra radiologi yang menunjukan nama dari file citra. Tombol detail ini berfungsi untuk menampilkan hasil citra yang sudah diproses sebelumnya, seperti pada Gambar 14.

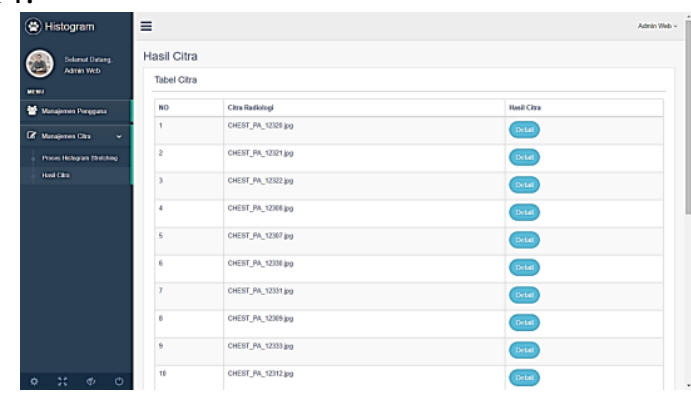

Gambar 13. Tampilan Halaman Log

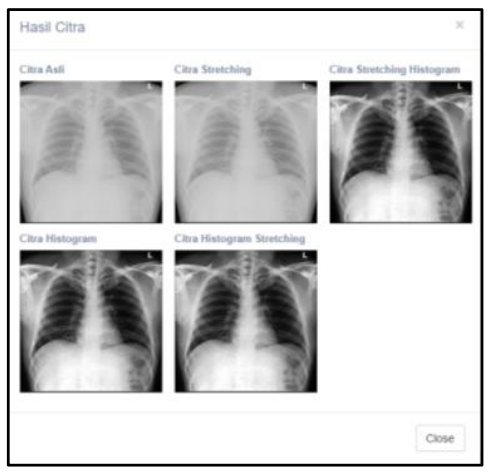

Gambar 14. Tampilan Fungsi Tombol Detail

\subsection{Pengujian}

Pengujian dalam penelitian ini mencakup dua bagian, yang pertama yaitu bagaimana penerapan secara sistem untuk metode Histogram Equalization, Contrast Stretching, dan gabungan metode Histogram EqualizationContrast Stretching untuk perbaikan kualitas citra radiologi. Kedua yaitu bagaimana penerapan secara manual untuk metode Histogram Equalization, Contrast Stretching, dan gabungan metode Histogram Equalization- 
Contrast Stretching untuk perbaikan kualitas citra radiologi.

\subsubsection{Penerapan Dengan Metode Histogram Equalization}

Penerapan metode Histogram Equalization yang dibahas dalam penelitian ini terdiri dari dua bagian, yaitu proses metode Histogram Equalization secara sistem dan proses metode Histogram Equalization secara manual sebagau berikut:

\section{Proses Metode Histogram Equalization} Secara Sistem

Aplikasi perbaikan kualitas citra radiologi pada penelitian ini menggunakan metode Histogram Equalization. Data yang digunakan berupa citra radiologi mentah dengan format .dcm, dan dilakukan konversi citra dari format .dcm menjadi format .jpg. Citra asli yang sudah dikonversi dapat dilihat pada Gambar 15.

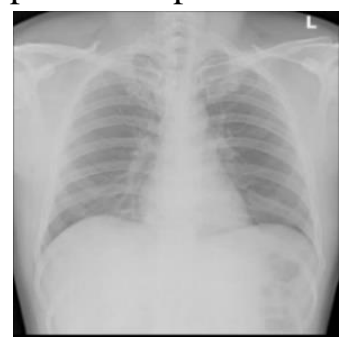

Gambar 15. Citra Asli

Setelah citra dikonversi, citra akan resize sebelum masuk ke proses perbaikan kualitas citra. Pada proses perbaikan kualitas citra dengan metode Histogram Equalization, piksel pada citra tersebut akan dikelompokkan dan dihitung jumlah piksel berdasarkan nilai keabuannya. Selanjutnya dilkukan memindai piksel dari nilai keabuan 0 sampai 255 untuk menemukan batas nilai keabuan terendah dan tertinggi. Dari piksel batas nilai keabuan terendah dan tertinggi akan dihitung peluang kemunculan setiap intensitas dan normalisasi. Hasilkan akan dibulatkan, dan dilakukan pemetaan piksel-piksel dengan skala yang digunakan 0 sampai 255 untuk citra 8 bit. Hasilnya dapat dilihat pada Gambar 16.

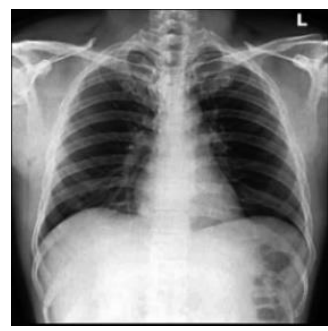

Gambar 16. Citra Hasil Pengolahan Metode Histogram Equalization
Dari hasil dapat dilihat untuk area trakea lebih terlihat dan rongga paru-paru lebih jelas. Sehingga citra hasil dikatakan lebih baik dari citra asli, karena citra hasil dapat digunakan untuk mendiagnosa.

2. Proses Metode Histogram Equalization

Secara Manual

Proses metode Histogram Equalization secara manual berisi perhitungan setiap tahap pemrosesan perbaikan citra radiologi denagn Histogram Equalization. Tahapan ini meliputi perhitungan mengubah citra RGB menjadi citra Grayscale. Citra asli yang digunakan pada proses manual dapat dilihat pada Gambar 17.
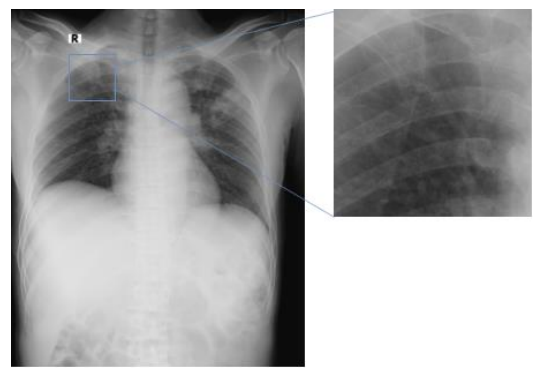

\section{Gambar 17. Citra Asli RGB}

Gambar 17 menunjukan citra asli yang mewakili RGB yang akan dimasukan pada aplikasi Matlab. Aplikasi Matlab digunakan untuk mengambil matriks RGB dari citra asli. Hasil citra yang dipotong memiliki nilai RGB yang berbeda-beda. Nilai RGB dapat dilihat pada Tabel 1.

Tabel 1. Nilai Piksel RGB Citra Asli

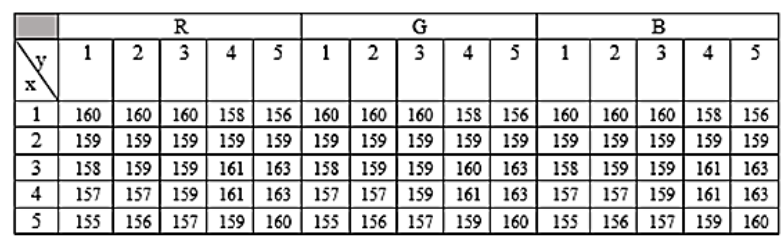

Tabel 1 merupakan nilai piksel RGB dari citra asli, yang diambil pada titik kolom sumbu $\mathrm{x} 1$ sampai titik kolom sumbu $\mathrm{x} 5$ dan pada baris sumbu y1 sampai baris sumbu y5. Selanjutnya menentukan nilai Grayscale menggunakan Persamaan 2 sebagai berikut:

Grayscale $=\frac{R+G+B}{3}$

Maka,

Grayscale $=\frac{160+160+160}{3}$

Grayscale $=\frac{480}{3}$

Grayscale $=160$ 
Menggunakan perhitungan yang sama, dilakukan perhitungan pada semua nilai piksel RGB citra asli. Hasil untuk nilai Grayscale yang telah dihitung dapat dilihat pada Tabel 2.

Tabel 2. Nilai Grayscale Citra Asli

\begin{tabular}{|c|c|c|c|c|c|}
\hline \multicolumn{7}{|c|}{ Grayscale } \\
\hline $\mathbf{x} y$ & 1 & 2 & 3 & 4 & 5 \\
\hline $\mathbf{1}$ & 160 & 160 & 160 & 158 & 156 \\
\hline 2 & 159 & 159 & 159 & 159 & 159 \\
\hline 3 & 158 & 159 & 159 & 161 & 163 \\
\hline 4 & 157 & 157 & 159 & 161 & 163 \\
\hline 5 & 155 & 156 & 157 & 159 & 160 \\
\hline
\end{tabular}

Setelah nilai Grayscale dari citra asli didapat, nilai maktriks tersebut diproses dengan metode Histogram Equalization. Nilai matriks diurutkan dari nilai terendah hingga nilai tertinggi dan dicari frekuensi kemunculan setiap pikselnya. Selanjutnya menghitung peluang kemunculan setiap piksel dan menghitung distribusi kumulatifnya. Untuk mencari nilai probabilitas dari intensitas piksel menggunkan Persamaan 3 sebagai berikut.

$P_{r}\left(r_{k}\right)=\frac{n_{k}}{n}$

Maka,

$P_{r}(155)=\frac{1}{25}$

$P_{r}(155)=0.04$

Setelah didapat hasil probabilitas dari tiap pikselnya, semua nilai probabilitas dihitung untuk mendapatkan nilai distribusi kumulatif dengan Persamaan 4 sebagai berikut:

$S_{k}=T\left(r_{k}\right)=\sum_{j=0}^{k} \frac{n_{j}}{n}=\sum_{j=0}^{k} P_{r}\left(r_{j}\right)$

Maka,

$S_{k}=0.04$

$S_{k}=0.04+0.08=0.12$

$S_{k}=0.12+0.12=0.24$

$S_{k}=0.24+0.08=0.32$

$S_{k}=0.32+0.36=0.68$

$S_{k}=0.68+0.16=0.84$

$S_{k}=0.84+0.08=0.92$

$S_{k}=0.92+0.08=1$

Setelah didapat nilai distribusi kumulatifnya, selanjutnya mengskalakan pikselpiksel dengan mengkalikan nilai distribusi kumulatif dengan sekala keabuan terbesar 0 sampai 255. Mengskalakan piksel-piksel dengan Persamaan 5 sebagai berikut:

$S=\left|S_{k}\right| x 255$
Maka,

$S=0.04 \times 255=10.2$

$S=0.12 \times 255=30.6$

$S=0.24 \times 255=61.2$

Persamaan 5 digunakan untuk mengskalakan semua nilai distribusi kumulatif. Hasil dari pengskalaan piksel kemudian dibulatkan dengan Persamaan 6. Untuk tabel perhitungan semua proses dapat dilihat pada Tabel 3.

Tabel 3. Perhitungan Histogram Equalization

\begin{tabular}{|c|c|c|c|c|c|}
\hline $\mathbf{r k}$ & nk & $\operatorname{Pr}(\mathbf{r k})=\mathbf{n k} / \mathbf{n}$ & $\mathrm{Sk}$ & $\mathrm{S}=|\mathrm{Sk}| \mathbf{x 2 5 5}$ & roundS=|Sk|x255 \\
\hline 155 & 1 & 0.04 & 0.04 & 10.2 & 10 \\
\hline 156 & 2 & 0.08 & 0.12 & 30.6 & 31 \\
\hline 157 & 3 & 0.12 & 0.24 & 61.2 & 61 \\
\hline 158 & 2 & 0.08 & 0.32 & 81.6 & 82 \\
\hline 159 & 9 & 0.36 & 0.68 & 173.4 & 173 \\
\hline 160 & 4 & 0.16 & 0.84 & 214.2 & 214 \\
\hline 161 & 2 & 0.08 & 0.92 & 234.6 & 235 \\
\hline 163 & 2 & 0.08 & 1 & 255 & 255 \\
\hline
\end{tabular}

Setelah semua proses telah dilakukan dan didapatlah piksel citra baru hasil dari penerapan metode Histogram Equalization. Nilai piksel citra baru yang sudah diperbaiki dapat dilihat pada Tabel 4 sebagai berikut.

Tabel 4. Nilai Citra Baru

\begin{tabular}{|r|r|r|r|r|r|}
\hline$x$ & 1 & 2 & 3 & \multicolumn{1}{|c|}{4} & \multicolumn{1}{|c|}{5} \\
\hline 1 & 214 & 214 & 214 & 82 & 31 \\
\hline 2 & 173 & 173 & 173 & 173 & 173 \\
\hline 3 & 82 & 173 & 173 & 235 & 255 \\
\hline 4 & 61 & 61 & 173 & 235 & 255 \\
\hline 5 & 10 & 31 & 61 & 173 & 214 \\
\hline
\end{tabular}

\subsubsection{Penerapan dengan Metode Contrast Stretching}

Penerapan metode Contrast Stretching yang dibahas dalam penelitian ini terdiri dari dua bagian, yaitu proses metode Contrast Stretching secara sistem dan proses metode Contrast Stretching secara manual sebagau berikut:

1. Proses Metode Contrast Stretching Secara Sistem

Untuk metode kedua aplikasi perbaikan kualitas citra radiologi ini menggunakan metode Contrast Sretching. Data yang digunakan berupa citra radiologi mentah dengan format .dcm, dan dilakukan konversi citra dari format $\mathrm{dcm}$ menjadi format jpg.

Setelah citra dikonversi, citra akan resize sebelum masuk ke proses perbaikan kualitas citra. Pada proses perbaikan kualitas citra dengan metode Contrast Stretching, piksel pada citra tersebut akan dikelompokkan dan dihitung jumlah piksel berdasarkan nilai keabuannya. 
Selanjutnya dilakukan memindai piksel dari nilai keabuan 0 sampai 255 untuk menemukan batas nilai keabuan terendah dan tertinggi. Nilai keabuan tertinggi dan terendah akan dipetakan untuk memenuhi rentang nilai-nilai keabuan yang lengkap dari 0 sampai 255 . Hasilnya dapat dilihat pada Gambar 18.

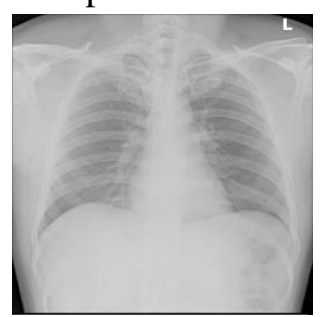

(a) Citra Asli

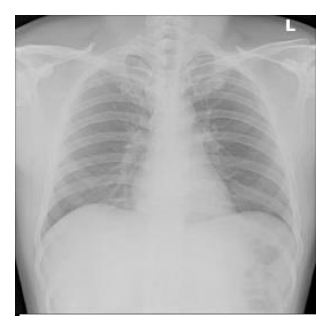

(b) Citra Hasil
Gambar 18. (a) Citra Asli dan (b) Citra Hasil Dengan Metode Histogram Equalization

Dari citra (a) dan (b) dapat dilihat dengan menggunkan metode Contrast Sretching menghasilkan citra yang mirip dengan citra asli. Sehingga area trakea dan rongga paru-paru tidak terlihat jelas. Dengan demikian hasil citra tidak dapat digunakan dalam membaca diagnosa.

2. Proses Metode Contrast Stretching Secara Manual

Proses metode Contrast Stretching secara manual berisi perhitungan setiap tahap pemrosesan perbaikan citra radiologi denagn Contrast Stretching. Tahapan ini meliputi perhitungan mengubah citra RGB menjadi citra Grayscale. Citra asli yang digunakan pada proses manual dapat dilihat pada Gambar 5.9. Citra asli yang mewakili RGB yang dimasukan pada aplikasi Matlab. Aplikasi Matlab digunakan untuk mengambil matriks RGB dari citra asli. Hasil citra yang dipotong memiliki nilai RGB yang berbeda-beda. Nilai RGB dapat dilihat pada Tabel 1. Matriks piksel RGB dari citra asli, yang diambil pada titik kolom sumbu $\mathrm{x} 1$ sampai titik kolom sumbu $\mathrm{x} 5$ dan pada baris sumbu $\mathrm{y} 1$ sampai baris sumbu y5. Selanjutnya menentukan nilai Grayscale menggunakan Persamaan 2 sebagai berikut:

Grayscale $=\frac{R+G+B}{3}$

Maka,

Grayscale $=\frac{160+160+160}{3}$

Grayscale $=\frac{480}{3}$

Grayscale $=160$
Menggunakan perhitungan yang sama, dilakukan perhitungan pada semua nilai piksel RGB citra asli. Hasil untuk nilai Grayscale yang telah dihitung dapat dilihat pada Tabel 2. Setelah nilai Grayscale dari citra asli didapat, nilai maktriks tersebut diproses dengan metode Contrast Stretching. Matriks Grayscale diurutkan dari yang terendah sampai yang tertinggi. Nilai keabuan tertinggi dan terendah akan dipetakan untuk memenuhi rentang nilainilai keabuan yang lengkap dari 0 sampai 255 . Untuk pemetaan digunakan Persamaan 7 sebagai berikut:

$Y=\left(X-x_{\min }\right)\left(\frac{l_{\max }-l_{\min }}{x_{\max }-x_{\min }}\right)+l_{\text {min }}$

Maka,

$Y=(155-155)\left(\frac{255-0}{163-155}\right)+0$

$Y=(0)\left(\frac{255}{8}\right)+0$

$Y=0$

Dengan menggunakan Persamaan 7, dilakukan perhitungan pada semua nilai matriks. Didapat nilai matriks seperti pada Tabel 5 sebagai berikut.

Tabel 5. Nilai Citra Baru

\begin{tabular}{|c|c|c|c|c|c|}
\hline $\begin{array}{c}\mathrm{y} \\
\mathrm{x}\end{array}$ & 1 & 2 & 3 & 4 & 5 \\
\hline 1 & 159 & 159 & 159 & 96 & 32 \\
\hline 2 & 127 & 127 & 127 & 127 & 127 \\
\hline 3 & 96 & 127 & 127 & 191 & 255 \\
\hline 4 & 64 & 64 & 127 & 191 & 255 \\
\hline 5 & 0 & 32 & 64 & 127 & 159 \\
\hline
\end{tabular}

\subsection{Pembahasan}

Dalam memperbaiki kualitas citra radiologi berdasarkan batasan masalah yang telah ditentukan terdapat 20 data citra radiologi yang akan diuji dengan ukuran piksel yang sama 500x500 piksel. Dari data citra yang sudah terkumpul sebanyak 20 data dilakukan proses perbaikan citra dengan metode Histogram Equalization, Contrast Stretching dan metode gabungan. Citra yang dihasilkan dari proses perbaikan akan dianalisa oleh pakar untuk melihat metode mana yang lebih baik. Data dan hasil pengujian dapat dilihat pada Tabel 6 . 
Tabel 6. Data dan Hasil Pengujian Citra Radiologi

\begin{tabular}{|c|c|c|c|c|c|c|}
\hline No. & Citra & $\begin{array}{l}\mathrm{H} \\
\mathrm{E}\end{array}$ & $\begin{array}{l}\mathrm{C} \\
\mathrm{S}\end{array}$ & $\begin{array}{c}\text { CS } \\
- \\
\text { HE }\end{array}$ & $\begin{array}{l}\mathrm{HE} \\
- \\
\mathrm{CS}\end{array}$ & Keterang-an \\
\hline 1 & $\begin{array}{l}\text { STF } \\
025\end{array}$ & & & & & $\begin{array}{l}\text { Trakea dan } \\
\text { rongga paru } \\
\text { lebih jelas }\end{array}$ \\
\hline 2 & $\begin{array}{l}\text { STF } \\
027\end{array}$ & & & & & $\begin{array}{l}\text { Rongga paru } \\
\text { lebih jelas }\end{array}$ \\
\hline 3 & $\begin{array}{l}\text { STF } \\
052\end{array}$ & & & & & $\begin{array}{l}\text { Trakea dan } \\
\text { rongga paru } \\
\text { lebih jelas }\end{array}$ \\
\hline 4 & $\begin{array}{l}\text { STF } \\
055\end{array}$ & & & & & $\begin{array}{l}\text { Rongga paru } \\
\text { lebih jelas }\end{array}$ \\
\hline 5 & $\begin{array}{l}\text { STF } \\
057\end{array}$ & & & & & $\begin{array}{l}\text { Rongga paru } \\
\text { lebih jelas }\end{array}$ \\
\hline 6 & $\begin{array}{l}\text { STF } \\
058\end{array}$ & & & & & $\begin{array}{l}\text { Trakea dan } \\
\text { rongga paru } \\
\text { lebih jelas }\end{array}$ \\
\hline 7 & $\begin{array}{l}\text { STF } \\
060\end{array}$ & & & & & $\begin{array}{l}\text { Trakea dan } \\
\text { rongga paru } \\
\text { lebih jelas }\end{array}$ \\
\hline 8 & $\begin{array}{l}\text { STF } \\
061\end{array}$ & & & & & $\begin{array}{l}\text { Trakea dan } \\
\text { rongga paru } \\
\text { lebih jelas }\end{array}$ \\
\hline 9 & $\begin{array}{l}\text { STF } \\
062\end{array}$ & & & & & $\begin{array}{l}\text { Trakea dan } \\
\text { rongga paru } \\
\text { lebih jelas }\end{array}$ \\
\hline 10 & $\begin{array}{l}\text { STF } \\
063\end{array}$ & & & & & $\begin{array}{l}\text { Trakea dan } \\
\text { rongga paru } \\
\text { lebih jelas }\end{array}$ \\
\hline 11 & $\begin{array}{l}\text { STF } \\
066\end{array}$ & & & & & $\begin{array}{l}\text { Rongga paru } \\
\text { lebih jelas }\end{array}$ \\
\hline 12 & $\begin{array}{l}\text { STF } \\
071\end{array}$ & & & & & $\begin{array}{l}\text { Trakea dan } \\
\text { rongga paru } \\
\text { lebih jelas }\end{array}$ \\
\hline 13 & $\begin{array}{l}\text { STF } \\
103\end{array}$ & & & & & $\begin{array}{l}\text { Trakea dan } \\
\text { rongga paru } \\
\text { lebih jelas }\end{array}$ \\
\hline 14 & $\begin{array}{l}\text { STF } \\
110\end{array}$ & & & & & $\begin{array}{l}\text { Trakea dan } \\
\text { rongga paru } \\
\text { lebih jelas }\end{array}$ \\
\hline 15 & $\begin{array}{l}\text { STF } \\
112\end{array}$ & & & & & $\begin{array}{l}\text { Trakea dan } \\
\text { rongga paru } \\
\text { lebih jelas }\end{array}$ \\
\hline 16 & $\begin{array}{l}\text { STF } \\
114\end{array}$ & & & & & $\begin{array}{l}\text { Trakea dan } \\
\text { rongga paru } \\
\text { lebih jelas }\end{array}$ \\
\hline 17 & $\begin{array}{l}\text { STF } \\
124\end{array}$ & & & & & $\begin{array}{l}\text { Rongga paru } \\
\text { lebih jelas }\end{array}$ \\
\hline 18 & $\begin{array}{l}\text { STF } \\
145\end{array}$ & & & & & $\begin{array}{l}\text { Trakea dan } \\
\text { rongga paru } \\
\text { lebih jelas }\end{array}$ \\
\hline
\end{tabular}

\begin{tabular}{|c|c|c|c|l|l|}
\hline 19 & STF \\
148 & & & & & $\begin{array}{l}\text { Trakea } \text { dan } \\
\text { rongga paru } \\
\text { lebih jelas }\end{array}$ \\
\hline 20 & STF & & & & $\begin{array}{l}\text { Trakea } \text { dan } \\
\text { rongga paru } \\
\text { lebih jelas }\end{array}$ \\
\hline
\end{tabular}

Keterangan:

$\mathrm{HE}=$ Histogram Equalization

$\mathrm{CS}=$ Contrast Stretching

CS-HE $=$ Contrast Stretching-Histogram Equalization

HE-CS = Histogram Equalization-Contrast Stretching

Pada tabel tersebut dapat dilihat bahwa metode yang paling baik terdapat pada metode gabungan CS-HE jika dibandingkan dengan metode lainnya. Dalam analisa ini yang menjadi parameter pakar adalah tampilan trakea dan ronggga paru-paru. Hasli perbaikan dengan metode gabungan CS-HE memiliki citra dengan trakea dan rongga paru-paru yang lebih jelas terlihat. Untuk metode HE dan metode gabungan HE-CS yang lebih terlihat hanya rongga paruparu saja. Citra tersebut nampilkan trakea yang terlalu putih sehingga sulit untuk membaca area tersebut. Sedangkan dengan menggunakan metode CS, hasil citra yang didapat kurang baik karena hasilnya mendekati citra asli sehingga kesulitan dalam mendiagnosa. Untuk menentukan presentase dari setiap metodenya digunakan Persamaan 8:

$$
\text { Persentase }=\frac{\text { jumlah keberhasilan }}{\text { jumlah data uji }} \times 100 \%
$$

Maka,

Persentase HE $=\frac{3}{20} \times 100 \%=15 \%$

Persentase CS $\quad=\frac{0}{20} \times 100 \%=0 \%$

Persentase $\mathrm{CS} \mid \mathrm{HE}=\frac{15}{20} \times 100 \%=75 \%$

Persentase $\mathrm{HE} \mid \mathrm{CS}=\frac{2}{20} \times 100 \%=10 \%$

Dari hasil perhitungan persentase didapat hasil sebagai berikut. Untuk metode HE dari hasil analisa menghasilkan persentase sebesar 15\% didapat dari 3 hasil perbaikan citra yang lebih baik dari metode lainnya. Untuk metode CS dari hasil analisa menghasilkan persentase sebesar 0\% didapat karena untuk metode CS yang cukup baik dan bisa digunakan untuk mendiagnosa. Untuk metode CS-HE dari hasil analisa menghasilkan persentase sebesar $75 \%$ 
didapat dari 15 hasil perbaikan citra yang lebih baik dari metode lainnya. Untuk metode HE-CS dari hasil analisa menghasilkan persentase sebesar 10\% didapat dari 2 hasil perbaikan citra yang lebih baik dari metode lainnya.

\section{KESIMPULAN DAN SARAN \\ 6.1 Kesimpulan}

Kesimpulan yang dapat diambil dari hasil pengujian dan analisis yang telah dilakukan pada aplikasi perbaikan kualitas citra radiologi adalah sebagai berikut:

1. Setelah dilakukan penelitian ini, didapat beberapa hasil perbaikan kualitas citra radiologi. Hasil perbaikan yang diproses menggunakan metode Histogram Equalization menunjukan area rongga paruparu yang terlihat jelas, sehingga citra dapat digunakan dalam analisa kesehatan area rongga paru-paru. Hasil perbaikan yang diproses menggunakan metode Contrast Stretching menunjukan area rongga paruparu dan trakea yang tidak terlihat jelas, sehingga citra tidak dapat digunakan dalam analisa kesehatan. Hasil perbaikan yang diproses menggunakan metode gabungan Contrast Stretching-Histogram Equalization menunjukan area rongga paru-paru dan trakea yang terlihat jelas, sehingga citra dapat digunakan dalam analisa kesehatan area rongga paru-paru. Hasil perbaikan yang diproses menggunakan metode gabungan Histogram Equalization-Contrast Stretching menunjukan area rongga paru-paru yang terlihat jelas, sehingga citra dapat digunakan dalam analisa kesehatan area rongga paruparu.

2. Dari hasil analisa pakar dapat persentase masing-masing metode perbaikan kualitas citra. Untuk metode HE menghasilkan persentase sebesar $15 \%$, untuk metode CS menghasilkan persentase sebesar $0 \%$, untuk metode gabungan CS-HE menghasilkan persentase sebesar $75 \%$ dan untuk metode gabungan HE-CS menghasilkan persentase sebesar 10\%. Dapat disimpulkan bahwa metode yang lebih baik untuk perbaikan kualitas citra radiologi adalah metode gabungan CS-HE.

\subsection{Saran}

Adapun saran untuk perbaikan dan pengembangan dari tugas akhir ini adalah:
1. Penelitian selanjutnya dapat menggunakan metode yang sama pada studi kasus citra radiologi berdasarkan jenis kelamin, lingkar dada, ataupun tinggi badan.

2. Penelitian selanjutnya dapat dibuat sebuah aplikasi untuk mendeteksi penyakit paruparu dengan mengunakan citra radiologi.

\section{DAFTAR PUSTAKA}

Malueka, R. (2007). Radiologi

[1] Diagnostik. Yogyakarta: Pustaka Cendekia.

Mau, S. D. (2016). Pengaruh Histogram qualization untuk Perbaikan Kualitas Citra Kupang: Universitas Katolik Mandira Kupang.

Ahmad, N. (2012). Metode Histogram Equalization Untuk Perbaikan Citra Digital Yogyakarta: Universitas Atmajaya Yogyakarta.

Nurliadi. (2016). Analisis Contrast Stretching Menggunakan Algoritma

[4] Euclidean Untuk Meningkatkan Kontras Pada Citra Berwarna. Medan: Universitas Sumatra Utara

Shaleh, M. (2015). Implementasi Contrast Stretching Untuk Perbaikan Kualitas Citra Digital Palembang: STMIK GI MDP

Gonzalez, R. C., \& Woods, R. E. (2002). Digital Image Processing Third Edition. New Jersey: Prentice Hall.

Purnomo, M. H. (2010). Konsep Pengolahan Citra Digital Dan Ekstraksi Fitur. Yogyakarta: GRAHA ILMU.

[8] Mohamad, d. I. (2014). Anatomi Klinis Dasar. Jakarta: PRIMA.

Malueka, R. (2007). Radiologi

[9] Diagnostik. Yogyakarta: Pustaka Cendekia.

Purnomo, M. H. (2010). Konsep

[10] Pengolahan Citra Digital Dan Ekstraksi Fitur. Yogyakarta: GRAHA ILMU.

Kadir, A., \& Susanto, A. (2013).

[11] Teori dan Aplikasi Pengolahan Citra. Yogyakarta: Yogyakarta: Andi. 